\title{
Lessons from the political economy of the New Deal
}

\author{
John Joseph Wallis*
}

\begin{abstract}
The New Deal produced a fundamental change in the structure of American government. The national government came to play a much larger role in the financing of social welfare programmes, while administration of the programmes was largely located at the states. Both the purely national and the shared 'federal' parts of the welfare system were characterized by impersonal rules. The political economy of how the rules came about and how the New Deal experience may have contributed to Americans changing their views on the danger of dealing with the national government is the primary focus. The paper closes with speculations about the possible effect of changing views on American participation in the Second World War after 1939.
\end{abstract}

Key words: Great Depression, New Deal, federalism, welfare programmes, relief programmes, institutions, Second World War

JEL classification: N12, N14, N42, N44, H10, H53, H75, H87

\section{Introduction}

The sequence of events beginning with the onset of the First World War I in 1914 and concluding with the post-war recovery to 1953 are (to date) the last great crisis of the developed world. ${ }^{1}$ Our current economic problems pale in comparison. After the inability of western European powers to coordinate their responses to each other's military build-up in the events leading to the First World War, the post-war settlement produced a fragile set of international arrangements for security and finance that could only work with the active and ongoing

\footnotetext{
*University of Maryland and NBER, e-mail: wallis@econ.bsos.umd.edu

This paper was written for the British Academy conference, 'Lessons from the 1930s Great Depression for the Making of Economic Policy', organized by Nick Crafts and Peter Fearon in April 2010. Comments from Nick, Peter, George Peden, Price Fishback, and Paul Hinderlie, two anonymous referees, and the conference participants were extremely helpful.

1 The introduction to Kennedy's Freedom From Fear (1999) lays out nicely why we must think of this entire period as interconnected, particularly if we are to understand the events of the 1930s and 1940s. doi: $10.1093 /$ oxrep/grq028

(C) The Author 2010. Published by Oxford University Press. For permissions please e-mail: journals.permissions@oxfordjournals.org.
} 
coordination of Britain, France, Germany, and the United States. Such coordination was not forthcoming. The United States, reluctant to enter the war in the first place, refused to ratify the League of Nations treaty and, as it had since the $1780 \mathrm{~s}$, remained suspicious and wary of entering deeper into foreign entanglements through international political and financial arrangements. A decade of economic recession in Europe in the 1920s was followed by a decade of worldwide depression in the 1930s. Deeper than any other economic crisis in modern history, the depression and its discontents produced radical political change in Germany, Spain, Italy, and other parts of Europe, and ultimately led to the deadliest war in human history. In both wartime and depression, the modern world failed to coordinate responses to economic and political crises that could have slowed or averted the onset of depression and war.

The Great Depression produced a different internal political response in the United States than in Europe. The new Democratic majority, led by Franklin Roosevelt, dramatically expanded social welfare programmes (relief), public infrastructure investment, financial regulation, and industrial cooperation - collectively called the 'New Deal'. Not all of these policies turned out to be successful or politically viable. In the earliest days of the Roosevelt administration, no one had a handle on what policies were best for encouraging recovery and ameliorating the effects of the depression. As other essays in this issue make clear, whether the policies adopted encouraged or discouraged recovery is still an open historical question. What is not open is that the attempts to ameliorate the effects of the depression profoundly changed the structure of the national government as well as state and local governments. From 1935 to 1939 a workable set of arrangements was put in place that resulted in a permanently larger public sector and a much more active national government. Americans solved a set of internal coordination problems.

When war began in Europe, despite vigorous isolationist resistance in the United States, a programme of support and coordination led to a much larger American presence in pre-war planning, the war effort itself, and in both the post-war recovery and the international attempts at coordination that followed. In the 1910s, 1920s, and early 1930s the United States had been unwilling to coordinate with European powers. Something had changed.

Economic historians and economists have thought a lot about the question of social coordination over the last half century. The prevailing explanation for the onset and depth of the Great Depression is that a set of policy failures, rooted in an inability to ensure international coordination in the face of an oncoming crisis, could have been prevented with a measure of international cooperation. ${ }^{2}$ Lack of coordination was the toxic residue of the Versailles Treaty. For economists, coordination problems arise when individuals see independent actions as being in their best interests as individuals, in contrast to actions that may be in the best interests of individuals as members of a larger community. The canonical example is the prisoner's dilemma. Two thieves are caught and put in separate cells, unable to communicate. Both are offered shorter prison terms if they testify first against the other and a longer term if the other prisoner talks first. The two prisoners are collectively better off if neither talks. Yet they can each see that if their partner does not cooperate with them and talks, they serve the longer prison term. Such incentives erode the possibility for coordinated action. For example, when the current economic crisis erupted in the fall of 2008, it was individually rational for people to retrench, reduce consumption, and increase savings. But rational individual behaviour might have been collectively damaging, as falling con-

2 Grossman and Meissner (2010); Eichengreen (1990, 1992, and 2007); Temin (1989). 
sumption leads to higher unemployment and economic contraction that make all individuals worse off. The invisible hand does not necessarily work to produce the best social outcomes in times when uncoordinated, but rational, individual behaviour lies at the root of the crisis. Collective response to collective crisis by attempts to increase demand through deficit spending and monetary expansion may be a way to coordinate collectively.

Coordination can be achieved in two fundamentally different ways. One is through coercion: by locating enough power in a single group or government to achieve coordination among all groups through threats. The other is through rules: by agreement on a set of relationships between groups that are credibly carried out. The first method accomplishes coordination by reducing the complexity of the problem, at the cost of empowering one group or organization above others. The second method accomplishes coordination by creating incentives for members of society to cooperate, even in specific situations where it may be in their interests not to coordinate, because the long-term value of the relationship outweighs the short-run benefits of defection.

This essay draws out aspects of the New Deal's domestic economic policy to advance our understanding of political problems of implementing economic policies in a way that ensures coordination through rules. At issue is the most important and longest lasting policy innovation of the New Deal: a federal system of social welfare programmes. The coordination problem was straightforward and hotly debated in the early 1930s: would the government impose taxes on individuals to fund social welfare programmes to aid the unemployed, and then use those funds to advance the political and economic interests of a minority? It was an economic policy of unprecedented size that worked politically because it implemented a set of institutional arrangements that solved the coordination problem. Both states and individuals were given credible guarantees that if they cooperated they would be treated impersonally-everyone was treated the same. Individuals' contributions to old-age insurance were treated the same no matter where the individual lived when they worked or retired. States were given the financial ability to ensure that the national government would treat all states on the same basis: states spent and the national government matched. The solution involved nothing less than an alteration in the fundamental constitutional arrangements between the three levels of government.

The particular institutions adopted in the New Deal social welfare revolution changed the relationship between individuals, state governments, and the national government. For the first time in American history, the national government undertook a major domestic responsibility and experience showed, by the end of the decade, that coordination was a surmountable problem. The domestic political transformation of the New Deal laid the foundation for the national government to dramatically expand its international role in the 1940s. The United States had not been willing to undertake large international commitments before 1939. Yet the outlines of the post-war international settlement were laid out in 1941, before the United States entered the war and followed the outlines of the American New Deal: a general commitment to economic policies to maintain incomes and eliminate poverty, selfdetermination, and open markets. ${ }^{3}$ After the war, the United States played a critical role in guaranteeing peace in Europe, supporting a coordinated European and Japanese recovery effort, and a new political order for the world. The origins of the institutional solutions that enabled the United States confidently, if reluctantly, to transform itself into a world power,

\footnotetext{
${ }^{3}$ Many may question whether the New Deal had a commitment to open markets, given its role in price supports in agriculture, cartels under the National Recovery Administration, and price supports for agriculture, but, in general, the New Deal stood behind private ownership and free markets.
} 
Figure 1: National government expenditure as a share of GDP, 1900-99

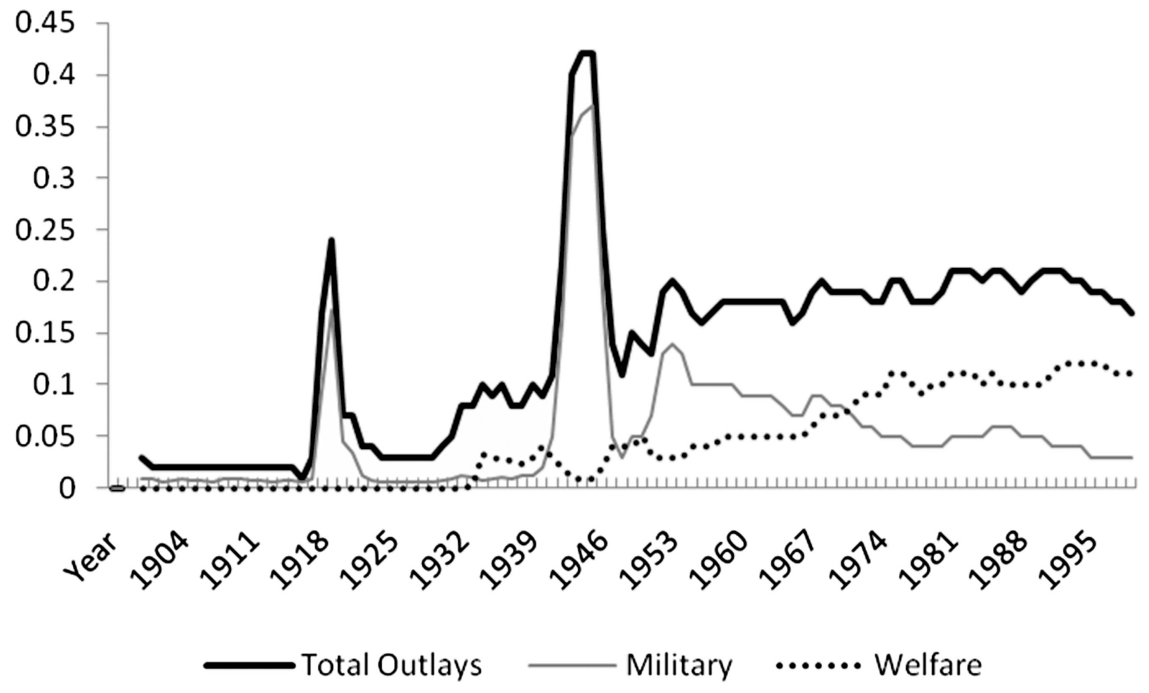

paralleled the institutional solutions devised during the New Deal to constrain and coordinate a much larger national government.

This short essay substantiates the domestic New Deal changes, but it can provide only a suggestive discussion of the international changes. Nonetheless, it is important to keep in mind that the international policies of the United States after 1939 were fundamentally different from after 1914 and, as a result, the world was different in the 1950s than in the 1920s. The United States mastered a set of political coordination problems in its domestic affairs in the 1930s; it did the same in its external affairs in the 1940s. A collection of essays assessing the lessons of the Great Depression of the 1930s for current economic policy-making should stop, for a least a moment, and think about these larger issues.

\section{A statistical overview}

The New Deal changed the constitutional allocation of government responsibilities between national, state, and local levels of government. The clearest way to see the changes is through fiscal data on expenditures. This is not the only way to appreciate what the national government was doing, but it gives a reliable overall picture. Until the 1930s, national government expenditures rarely exceeded 4 per cent of GDP in any years except war years and their immediate aftermath. Figure 1 shows total national government outlays as a share of GDP from 1900 to 1999 , as well as detail for military expenditures and for social welfare. ${ }^{4}$ The annual numbers on total outlays, military spending, and social welfare spending as a share of GDP are given in Table 1, as well as military and welfare spending as a share of total outlays.

\footnotetext{
${ }^{4}$ National social welfare expenditures at zero until 1933, then taken as annual expenditures for cooperatively administered relief programmes from Wallis (1984) until 1939, and then taken as the Office of Management and Budget (OMB) category of 'human resources', which includes Social Security, Medicare, and Medicaid, as well as other welfare programmes.
} 
Table 1: National government outlays: total, military, and welfare (as percentage of GDP and percentage of total outlays)

\begin{tabular}{|c|c|c|c|c|c|}
\hline & $\begin{array}{l}\text { National } \\
\text { outlays } \\
\% \text { of GDP } \\
\text { (1) }\end{array}$ & $\begin{array}{l}\text { Military } \\
\text { expenditures } \\
\% \text { of GDP } \\
\text { (2) }\end{array}$ & $\begin{array}{l}\text { Welfare } \\
\text { expenditures } \\
\% \text { of GDP } \\
\text { (3) }\end{array}$ & $\begin{array}{l}\text { Combined } \\
\% \text { of GDP } \\
\text { (4) }\end{array}$ & $\begin{array}{l}\text { Combined } \\
\% \text { of outlays } \\
\text { (5) }\end{array}$ \\
\hline 1923 & 4 & 0.8 & 0 & 1 & 22 \\
\hline 1924 & 3 & 0.7 & 0 & 1 & 22 \\
\hline 1925 & 3 & 0.7 & 0 & 1 & 21 \\
\hline 1926 & 3 & 0.6 & 0 & 1 & 20 \\
\hline 1927 & 3 & 0.6 & 0 & 1 & 20 \\
\hline 1928 & 3 & 0.7 & 0 & 1 & 22 \\
\hline 1929 & 3 & 0.7 & 0 & 1 & 22 \\
\hline 1930 & 4 & 0.8 & 0 & 1 & 22 \\
\hline 1931 & 5 & 1.0 & 0 & 1 & 20 \\
\hline 1932 & 8 & 1.2 & 0 & 1 & 15 \\
\hline 1933 & 8 & 1.1 & 0 & 1 & 17 \\
\hline 1934 & 10 & 0.8 & 3 & 4 & 40 \\
\hline 1935 & 9 & 1.0 & 3 & 4 & 45 \\
\hline 1936 & 10 & 1.1 & 3 & 4 & 38 \\
\hline 1937 & 8 & 1.0 & 3 & 4 & 43 \\
\hline 1938 & 8 & 1.2 & 2 & 4 & 45 \\
\hline 1939 & 10 & 1.2 & 3 & 4 & 42 \\
\hline 1940 & 9 & 2 & 4 & 6 & 61 \\
\hline 1941 & 11 & 5 & 3 & 8 & 78 \\
\hline 1942 & 22 & 16 & 2 & 18 & 83 \\
\hline 1943 & 40 & 34 & 1 & 35 & 88 \\
\hline 1944 & 42 & 36 & 1 & 37 & 89 \\
\hline 1945 & 42 & 37 & 1 & 38 & 91 \\
\hline 1946 & 25 & 19 & 2 & 22 & 87 \\
\hline 1947 & 14 & 5 & 4 & 9 & 66 \\
\hline 1948 & 11 & 3 & 4 & 7 & 64 \\
\hline 1949 & 15 & 5 & 4 & 9 & 62 \\
\hline 1950 & 14 & 5 & 5 & 10 & 66 \\
\hline 1951 & 13 & 7 & 3 & 10 & 76 \\
\hline 1952 & 19 & 13 & 3 & 16 & 85 \\
\hline 1953 & 20 & 14 & 3 & 17 & 85 \\
\hline 1954 & 19 & 13 & 3 & 16 & 88 \\
\hline 1955 & 17 & 10 & 4 & 14 & 84 \\
\hline 1956 & 16 & 10 & 4 & 13 & 83 \\
\hline 1957 & 17 & 10 & 4 & 14 & 83 \\
\hline 1958 & 18 & 10 & 5 & 15 & 84 \\
\hline 1959 & 18 & 10 & 5 & 15 & 80 \\
\hline 1960 & 18 & 9 & 5 & 14 & 81 \\
\hline
\end{tabular}

Source: Historical Statistics, Outlays and Expenditures: Series EA644 and EA704 (total outlays), EA645 and EA705 (military), and EA711 (welfare/human resources), and Wallis (1984) (relief expenditure 1933-9). GDP from Johnston and Williamson (2008).

The figure and table illustrate several important phenomena. First, the impact of the First and Second World Wars are immediately apparent in the two spikes. Second, the peacetime size of the national government grew significantly from the early 1930 s to the early 1950 s. Third, since the early 1950s, national government outlays have fluctuated within a fairly narrow range between 18 and 22 per cent of GDP (with a few years of 16 and 17 per cent in the 1950s). There was no trend upwards in national expenditures as a share of GDP from 1953 to 2008 ! Fourth, the composition of expenditures changed gradually and persistently. 
Figure 2: Expenditure shares by level of government for the twentieth century, excluding military and interest outlays of the national government

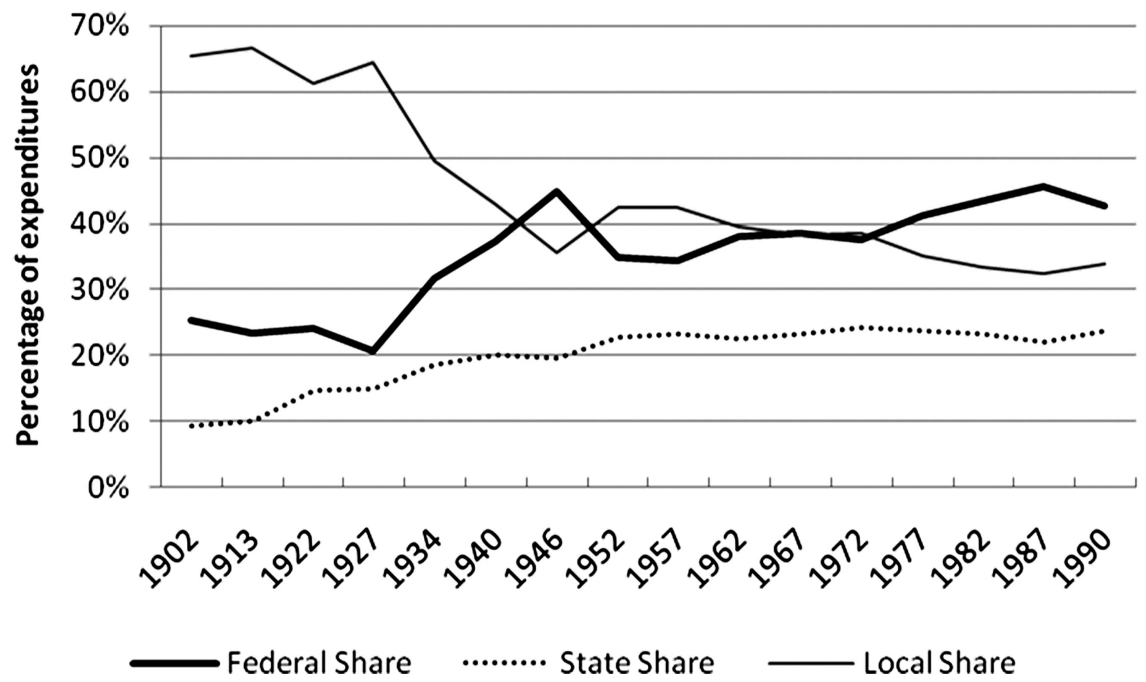

Source: From Wallis and Oates (1998).

In the 1950 s, military expenditures were roughly 10 per cent of GPD, welfare expenditures were roughly 5 per cent, and together they accounted for about 80 per cent of national outlays (column (5)). The military share of expenditures drifted downwards after 1970 - by the 1990s it was in the neighbourhood of 4 per cent of GDP - and the social welfare share drifted upwards to between 11 and 12 per cent of GDP in the 1990s. The two functions, however, continue to account for between 75 and 80 per cent of national outlays for the remainder of the century (and still did in 2008). ${ }^{5}$

It is not just that national government commitments to social welfare programmes and military spending were very small prior to the 1930s and very large after the 1950 s. There is nothing else capable of explaining the increased fiscal size of the national government. But there is a catch. Social welfare expenditures do not rise steadily from 1933, and defence spending (accounting for war-time increases) does not rise steadily from 1945. Commitments were made to perform both these government functions at a much higher level, but plenty of time transpired between when the commitments were made and when the national government was faced with the cost of honouring them.

The other important statistical element is the changing relative size of the three levels of government. Figure 2 reports expenditure shares by level of government for the twentieth century, excluding military and interest payments by the national government. This is the 'domestic' side of government. Expenditures from grant programmes are attributed to the receiving government, so national government grants to state and local governments are treated as state and local, not national, expenditures. The figure shows the sharp increase in the

\footnotetext{
5 The lowest the combined share of the two functions in total outlays since 1960 has been was 73 per cent in fiscal year 1991. In fiscal year 2008 national defence and human resources account for 17.4 per cent of GDP, out of total national government outlays of 20.7 per cent of GDP (OMB numbers).
} 
national government in the 1930s matched with a comparable decline in the share of local governments. The figure also shows a steadily increasing share of state government expenditures. The decline of local and rise of state expenditures suggests that more than a simple expansion of the national government took place in the 1930s.

\section{The New Deal, 1933 to 1939}

When Franklin D. Roosevelt (FDR) took office in March 1933, unemployment stood at 25 per cent of the labour force. Over the previous 3 years, real income and the price level both dropped 25 per cent, nominal income by almost 50 per cent. The banking and financial system had ground to a near halt and stood on the edge of a complete collapse. Roosevelt immediately called an emergency session of Congress. In their first hundred days Roosevelt and the new Democratic majority in Congress passed significant legislation affecting banking and finance, securities markets, relief (social welfare), business regulation, public utilities, and infrastructure investment. Many of these New Deal programmes appear in other papers in this volume. In sheer fiscal terms and in direct impact on families and individuals, no programme was more important than relief.

Relief policies were not directed at promoting economic recovery, but providing assistance to those harmed by the depression. Economists often ignore the political and social value of relief, preferring to focus solely on whether a programme aided or retarded the process of recovery and growth. This is a particularly myopic perspective when thinking about an economic catastrophe such as the Great Depression. The viability of political leaders, individuals as well as parties, is critical to implementing economic policies. In a democracy, leaders like Hoover and the Republicans, who did not project (or accomplish) a sense of compassion for those adversely affected by an economic crisis, cut political support out from underneath themselves. Roosevelt realized this from the beginning, and the New Deal never seriously questioned its commitment to helping people. Subsequent economic analysis of the effect of the relief programmes on private employment has produced mixed results, but the fairly robust conclusion is that the effect of relief spending on employment, whether it was positive or negative, was small. ${ }^{6}$

That said, the relief programmes also represented the 'conservative achievements of liberal reform' to borrow Barton Bernstein's phrase (1968). Americans had a long history of concern with the deleterious effect of relief on private incentives to work. ${ }^{7}$ The Federal Emergency Relief Administration and the categorical relief programmes were means tested, with cash grants that declined with the income of the recipient. National relief administrations were always attempting to get states to spend more money, rather than less. The problem facing the Democrats was not runaway relief expenditures but rather, as we will see, a tendency to allocate too little for relief or to contract relief too fast.

The history of the New Deal relief programmes falls into two eras: May 1933 to the summer of 1935, and after the summer of 1935. The two periods are distinguished by the type and amount of administrative discretion exercised by the national government and the discretion remaining in the hands of state and local officials. Table 2 provides a list of the major New Deal relief programmes. The first period was a chaotic time when national, state, and

\footnotetext{
${ }^{6}$ Fishback (2010) discusses the relevant empirical literature.

${ }^{7}$ See Katz (1986) and Patterson (1986) for histories of welfare policies in the United States.
} 
Table 2: Major relief programmes, dates, and administrative character

\begin{tabular}{llll}
\hline Started & \multicolumn{1}{c}{ Ended } & \multicolumn{1}{c}{ Agency } & Administration \\
\hline May 1933 & Autumn 1935 & Federal Emergency Relief Administration (FERA) & Federal \\
April 1933 & July 1942 & Civilian Conservation Corp (CCC) & National \\
November 1933 & March 1934 & Civil Works Administration (CWA) & National \\
Spring 1935 & 1942 & Works Progress/Projects Administration (WPA) & National/Federal \\
1935 & $1994^{\mathrm{b}}$ & Rural Electrification Administration (REA) & National \\
1937 & $1946^{\mathrm{c}}$ & Farm Security Administration (FSA) & National \\
Summer 1935 & Present & Old Age and Survivors Insurance (OASI) & National \\
Summer 1935 & Present & Unemployment Insurance & Federal \\
Summer 1935 & $1974^{\mathrm{d}}$ & Old Age Assistance (OAA) & Federal \\
Summer 1935 & $1974^{\mathrm{d}}$ & Aid to the Blind & Federal \\
Summer 1935 & $1996^{\mathrm{e}}$ & Aid to Dependent Children (ADC) & Federal \\
\hline
\end{tabular}

Notes: Federal administration refers to joint administration by the state and national governments. National administration refers to programmes administered by the national government. General relief was provided by local governments throughout the period. ${ }^{a}$ Some FERA projects were phased out over a period lasting through March 1937. ${ }^{b}$ The REA in 1949 was authorized to make loans for telephone improvements and in 1988 was permitted to give interest-free loans for job creation and rural electric systems. Its duties were assumed by the Rural Utilities Service when it was abolished in 1994. ${ }^{\mathrm{c}}$ The FSA took over the role played by the Resettlement Administration begun in 1935. Some of its programmes were eventually taken over by the Farmers Home Administration in 1947. ${ }^{d}$ Old-age assistance and aid to the blind were almost entirely superseded by the Supplemental Security Income Program in 1974 . ${ }^{e}$ Aid to Dependent Children was renamed Aid to Families with Dependent Children in 1962 and the programme was replaced by Temporary Aid for Needy Families in 1996. Sources: National Resources Planning Board (1942, pp. 26-97); Alston and Ferrie (1999, pp. 91-8).

local politicians and administrators felt their way towards a sustainable social welfare system. In May 1933, the Federal Emergency Relief Act created the Federal Emergency Relief Administration (FERA), the largest and most important relief programme up to 1935. Roosevelt chose Harry Hopkins as the FERA Administrator. The original act appropriated $\$ 500 \mathrm{~m}$ to be allocated among the states, half on a matching basis and half at the discretion of the administrator.

Although Hopkins had been in charge of the Temporary Emergency Relief Administration in New York under Roosevelt as governor, no one had a grasp of the scale of the relief problem or what it would take to deal with the depression. It soon became apparent that the relief effort required a great deal more funding. Congress appropriated roughly $\$ 2$ billion a year to be allocated between the states at Hopkins's discretion through a series of emergency acts. Once funds were granted, however, FERA funds legally became the property of the states. The FERA system had a completely centralized method of allocating funds between the states at the discretion of the relief administrator, combined with a completely decentralized system of relief administration. Hopkins attempted to raise the standards of relief administration, but his ability to do so was limited by the relative independence of state relief administrations. Hopkins's primary tool was discretionary allocations of relief funds. He could, and did, threaten to withhold federal grants for relief to states with corrupt, politically manipulative, or inefficient relief administrations. Withholding funds, however, was a blunt policy tool that worked to the direct disadvantage of the unemployed in the state, in contradiction to FERA's mandate.

The Democrats learned over the first 2 years. In 1935, Roosevelt submitted a programme for a more permanent relief system to Congress. As passed, the Social Security Act provided a permanent, nationally administered programme of old-age insurance, what is called Social Security today. The act also provided for a national payroll tax for unemployment insurance 
Table 3: National government revenues, outlays, and expenditures on cooperative programmes and relief programmes, 1929-40 (millions of nominal dollars)

\begin{tabular}{|c|c|c|c|c|c|}
\hline & $\begin{array}{l}\text { National } \\
\text { revenues } \\
\text { (1) }\end{array}$ & $\begin{array}{l}\text { National } \\
\text { outlays } \\
\text { (2) }\end{array}$ & $\begin{array}{l}\text { Outlays - outlays in } \\
1933 \\
\text { (3) }\end{array}$ & $\begin{array}{l}\text { Cooperative } \\
\text { programmes } \\
\text { (4) }\end{array}$ & $\begin{array}{l}\text { Relief } \\
\text { programmes } \\
\text { (5) }\end{array}$ \\
\hline 1929 & 3,861 & 3,127 & & & \\
\hline 1930 & 4,057 & 3,320 & & & \\
\hline 1931 & 3,115 & 3,577 & & & \\
\hline 1932 & 1,923 & 4,659 & & & \\
\hline 1933 & 1,996 & 4,598 & 0 & 432 & 154 \\
\hline 1934 & 3,014 & 6,644 & 2,046 & 2,857 & 2,126 \\
\hline 1935 & 3,795 & 6,497 & 1,899 & 3,649 & 2,221 \\
\hline 1936 & 3,997 & 8,421 & 3,823 & 3,969 & 2,343 \\
\hline 1937 & 4,955 & 7,733 & 3,135 & 4,273 & 2,405 \\
\hline 1938 & 5,588 & 6,764 & 2,166 & 3,518 & 2,047 \\
\hline 1939 & 4,979 & 8,841 & 4,243 & 4,794 & 2,671 \\
\hline 1940 & 6,879 & 9,055 & 4,457 & 3,922 & 2,188 \\
\hline Total & & & 21,769 & 27,414 & 16,155 \\
\hline
\end{tabular}

Source: Wallis (1984). Note that all of the relief programmes, column (5), were 'cooperative' and therefore are included in the total for cooperative programmes, column (4).

programmes run by the individual states; 90 per cent of the payroll taxes paid in each state were held in trust for that state. Finally, the act provided relief for three categories of persons: old-age assistance, aid to the blind, and aid to dependent children. The categorical programmes were financed from general revenues and allocated among the states by strict matching grants. The amounts of national grants to states were therefore determined solely by state expenditures. It was the states, and not the national government, which controlled spending on the categorical programmes. As a result, the welfare programmes were distinctly 'federal' programmes, involving all three levels of government.

The complementary element of the 1935 reforms was the creation of an 'emergency' relief programme, funded by a series of ongoing emergency relief appropriation acts (ERAAs). Under the act of 1935, Roosevelt created the Works Progress Administration (WPA), and a number of smaller relief programmes: the National Youth Administration, the Rural Electrification Administration, the Farm Security Administration, and others. The WPA, also headed by Hopkins, was structured so that Roosevelt could make discretionary allocations between the states and, importantly, WPA officials retained the right to approve individual projects within states. Infrastructure investment became part of the relief programme through 'work relief'. The WPA also financed a number of nationally administered programmes in the arts, theatre, literature, and history that did not have state or local sponsors. After the summer of 1935, the WPA was the largest single relief programme and the largest public-works agency.

The permanent part of the welfare system was put in place by the Social Security Act and placed most administrative discretion, including control over spending, at the state level. The emergency part of the welfare system, which would disappear as soon as the economic crisis was over, was also distinctly 'federal', but placed slightly more control in the hands of the national government and the executive branch. ${ }^{8}$

\footnotetext{
${ }^{8}$ Congress steadily eroded the discretion of the national WPA administration, eventually moving to a loose matching system for making grants — state and local governments were required to put up 25 per cent of the funds for most projects - similar to the strict matching formula in the categorical grant programmes.
} 
In fiscal terms, the relief programmes were enormous. In fiscal year 1934, just the national portion of relief expenditures was $\$ 2.1$ billion at a time when GDP was $\$ 60$ billion ( $\$ 56$ billion in 1933, $\$ 66$ billion in 1934). Table 3 gives national government revenues and expenditures from 1929 to 1940, as well as expenditures on 'cooperatively administered' programmes and relief programmes from 1934 to 1940. If we take Hoover's fiscal 1933 expenditures as a base line, nominal New Deal expenditures increased by $\$ 21$ billion between 1934 and 1940, and relief programmes alone account for \$16 billion of the increase. ${ }^{9}$ In cooperatively administered programmes the national government provided the funds, but state and local governments actually administered the programmes, including relief, public works and infrastructure, highways, and agricultural support programmes. Cooperative programmes account for \$27 billion, more than the entire increase of New Deal expenditures over Hoover's 1933 budget.

It is hard to over state the effect this had on the American political system. The national government, which had previously played a major fiscal role only in times of war, was passing out between $\$ 3$ and $\$ 4$ billion a year for relief, for construction of highways, bridges, other infrastructure, and for aid to farmers. Almost all of the money went through state and local governments. There were no rules in 1933 for how the money would be spent, for there was no precedent for doing this. The relevant question for our purposes is how were New Deal funds passed out? Did states need to worry that their tax dollars would end up in other states?

In the summer of 1933, it seemed pretty clear that states did need to worry. FERA's goal was getting the maximum amount of relief to the largest number of people, quickly, and with a minimum of administrative costs. The state and local share of relief expenditures varied from a high of 62 per cent in Rhode Island to a low of 5.4 per cent in Alabama. There was constant friction between FERA and state governments over the administration and financing of relief. Hopkins threatened to withhold FERA grants to several states that refused to increase state contributions. The disputes were significant in 12 states. He made good on his threat to withhold funds in Colorado and Missouri. Dissatisfaction with the way relief was administered led Hopkins to take over, or 'federalize' the administration of relief in six states. ${ }^{10}$ In North Dakota, Governor Langer was indicted and convicted for extorting kickbacks from federal government employees, although he wiggled out of serving jail time. In Ohio, Governor Davey had a feud with Hopkins over the administration of relief.

As the Social Security bill, put before Congress in January of 1935, moved forward, states and their representatives in the House and Senate acted to protect their interests against the national government's. The key provision that enabled Hopkins to manipulate the states under FERA was his discretionary control over the allocation of grants to the states. By

\footnotetext{
9 As Fishback (2010) notes, expenditures had risen substantially under Hoover (see Table 3).

${ }^{10}$ The six states were Oklahoma, North Dakota, Massachusetts, Ohio, Georgia, and Louisiana. Federal officials federalized relief in Oklahoma on 23 February 1934, when the governor announced that he would not apply for relief unless he had control over the distribution; in North Dakota on 1 March 1934, as the result of charges that employees of the state relief administration were being assessed for political contributions; for work relief in Massachusetts on 7 March 1934, because the state had a statute that all grants from the state had to be distributed on a population basis not on a need basis; in Ohio on 16 March 1935 in a dispute over whether Ohio had supplied a fair share of relief funds; and in Louisiana (8 April 1935) and Georgia (19 April 1935) owing to long-running disputes between the governors and federal administrators over the use of the funds. Hopkins withheld funds from Colorado in December 1933 and from Missouri in April 1935 until the state legislatures produced funds to help pay for relief. Threats to withhold funds went out to Alabama and Kentucky in 1933 and to Illinois in 1934. See E. A. Williams (1939, pp. 170-8, 203-5).
} 
the time the Social Security bill emerged from committee in the House, that discretionary power had been removed from the national administrator. All of the categorical welfare programmes were funded by strict, closed-end matching grants, and unemployment insurance trust funds were segregated by state. Congress imposed these restrictions on the Roosevelt administration. In addition, the Social Security Board, created by the act, was explicitly prohibited from interfering with personnel policies of the state administration or withholding matching funds because of personnel policies. Control over patronage in unemployment insurance and categorical relief programmes was firmly located at the state and local level. ${ }^{11}$

In other areas national prerogatives held. There was a determined attempt to modify the old-age insurance programme from a nationally administered programme, in which every participant received benefits based on their contributions, no matter where they lived in the country when they worked or when they retired, to a publicly subsidized privately administered programme. The administration was able to thwart attempts to decentralize the administration of old-age insurance by judicious use of the $\$ 4.8$ billion in relief funds placed at Roosevelt's discretion in the ERAA of 1935 in March. Roosevelt was intimately involved in the allocation of the ERAA funds. Every week Hopkins, Harold Ickes (the head of the Public Works Administration), and Roosevelt met to allocate funds between projects, in states and congressional districts throughout the country. The week after the Social Security Act passed, the remaining funds were allocated and the group stopped meeting (Wallis, 1981, 1991).

The Social Security Act was a compromise between the executive and legislative branches of government, but, more importantly, it implemented a new constitutional arrangement between the states and the national government that guaranteed two features of the new social welfare system. Old-age insurance became a national programme, administered in a completely impersonal way. Individuals and employers made monthly contributions and beneficiaries received the same benefits no matter where they lived or worked. Old-age insurance would be completely impersonal.

In contrast, relief between 1933 and 1935 had been administered by local and state governments on a case-by-case basis. Relief benefits were related to an assessment of need. Similar need-based evaluations would be part of categorical relief under the Social Security Act. The administration of unemployment insurance, aid to the blind, old-age assistance, and aid to dependent children remained with the state governments, but they were administered under a set of financial arrangements that prevented the national government from exerting fiscal pressure on the states. Welfare administration was also 'impersonal', only it was the states that were treated impersonally not the individual recipients. States were free to set their own welfare administration and standards, subject to oversight by the Social Security Board. The result was a wide variety of benefits and programmes across the country, and an ongoing debate for the remainder of the twentieth century over the nature of welfare in the states. ${ }^{12}$

The division of responsibility between the permanent branch of the welfare system and the emergency branch is revealing. The Social Security Act provided assistance for 'categories' of individuals who deserved support because of their condition: the old, mothers and dependent children, the blind, and the temporarily unemployed. The WPA and other emer-

11 For detailed consideration the Social Security Act and its adoption, see Wallis (1981, 1991). For the importance of patronage in the administration of relief, particularly in the south, see Alston and Ferrie (1999).

12 There is an extensive literature on various aspects of equality in the New Deal, most explicitly addressing the reluctance to make New Deal policies impersonal with respect to race. See Alston and Ferrie (1999) in this regard, and also Whately (1983), Grant (1990), Lieberman (1998), Brown (1999), and Katznelson (2005). 
gency relief programmes provided assistance for those who were suffering from the current economic crisis, but could be expected to support themselves when the economy recovered. Funding for the emergency programmes was renewed by Congress every year. In 1937, hoping that recovery had advanced enough, the Democrats cut back on WPA funding. The drop is apparent in all of the tables. The reduction in relief spending, combined with the monetary restriction imposed by the Federal Reserve Board's raising of reserve requirements in 1937, put the economy back into a second recession in 1938. All of the adjustments in spending occurred in the emergency part of the relief programmes.

There was nothing inevitable about these administrative arrangements; they could have been significantly different. When the Roosevelt administration began spending $\$ 2$ billion a year on relief, the political benefits of doing so were immediately apparent, but how the political benefits were to be distributed within the political system was not clear. A nationally funded system with very little discretion for national administrators to use the funds for political purposes eventually emerged. Democrats in Congress managed to have their cake and eat it too. They designed a permanent social welfare system controlled by the states and an old-age insurance system with impersonal benefits, at the same time that they gave their party leader, Roosevelt, control over a $\$ 4.8$ billion war chest to influence current politics. It was a neat solution to a difficult problem.

Few people in the 1930s thought that politics had been taken out of the administration of social welfare. Indeed, the solution that emerged in the Social Security Act was deeply political, but the system did remove the day-to-day manipulation of public funds for political purposes. Economic historians have devoted a great deal of attention to answering the question as to whether Roosevelt played politics with national grants to the states. The literature began with Arrington $(1969,1970,1983)$ and Reading's (1973) investigations, and was redirected by Wright's (1974) paper that explicitly introduced measures of 'political productivity'. Many others have followed, including myself. ${ }^{13}$ Most of this work focuses on the statistical effect of political variables in comparison to the effect of economic variables on the allocation of national grants between the states between 1933 and 1940, or the allocation of national grants between counties for the entire decade. Interest in these kinds of questions endures because of the possibility of showing that Roosevelt and the Democrats were disingenuous when they professed to desire 'relief, recovery, and reform', when in fact they were simply motivated by getting re-elected. This literature does not result in an explanation for the New Deal, but only an inference about the motivations behind New Deal allocations. ${ }^{14}$

The problem with testing for 'political' effects by examining the statistical effect of 'political' variables is that even if politics had played no role in the allocation of New Deal spending between the states, that does not imply that the administration and structure of relief, public works, and agriculture did not have significant political effects. In the early days of the New Deal, when Harry Hopkins disbursed \$2 billion a year to state governments, roughly one-fifth of American families received a cash payment from the government every month. Congressmen, governors, and politicians at every level wanted to get their hands on some of

13 For a sampling see Wallis $(1984,1987,1991,1998,2001)$, Anderson and Tollison (1991), Couch and Shughart (1998, 2000), Fleck (1999a,b, 2001a,b, 2008), Bateman and Taylor (2003, 2007), Fishback et al. (2001, 2007), Fishback et al. (2003), Fishback et al. (2005, 2006), Fishback et al. (2010), and Wallis et al. (2006).

${ }^{14}$ The work of Fishback and Kantor, along with several co-authors cited in the previous footnote, asks much more substantial questions about the effect of New Deal programmes on the economy and society in the 1930s. Fleck (2008) is the only serious attempt to say that the New Deal resulted from the pattern of political benefits at issue in this literature. 
that money. There was no apolitical alternative, no way of passing out relief funds or publicworks funds that had a neutral impact on politics. An allocation formula based on the number of unemployed, the number of relief cases in the previous quarter, per capita income, wages, or any other economic variable still had political ramifications.

The fundamental accomplishment of the New Deal political economy was to accommodate these political forces within an institutional structure that balanced competing interests at the state and national level, administered old-age insurance in a way that was truly impersonal, and had a relief administration that was widely regarded as not corrupt. ${ }^{15}$ Unlike the early days of the New Deal, when Hopkins possessed the discretionary power to coerce states, under the Social Security Act the national relief administration possessed the power to coordinate the states. The United States had moved from being a laggard in the provision of social welfare services when compared to European countries to more active (if still limited) government involvement.

A comparison with Germany is instructive. On 1 February, 2 days after his appointment as Chancellor, Hitler made his first radio address. In it, he promised a programme to 'rescue the German peasantry from poverty and to overcome the unemployment of German workers'. ${ }^{16}$ Hitler inherited a $600 \mathrm{~m}$ Reichsmarks work programme from his predecessor. Efforts to create work peaked in the spring of 1934, when 1,075,000 individuals were on work programmes, but the work programme quickly dissolved. Unlike the United States, where the administration of relief was relocated from national to state and local governments, in Germany the work programme served as a vehicle for consolidating power and funds at the national level. Roughly $250 \mathrm{~m}$ Reichsmarks of the original $600 \mathrm{~m}$ were funnelled into the military budget. Spending after the spring of 1934 came at the expense of national transfers to local governments, rather than supplementing national transfers to local governments.

In large part, Reich work creation spending simply 'repackaged' funds that might otherwise have been spent by local governments. . . . A state-driven economic recovery went hand in hand with unprecedented centralization of public spending, of which the military were the prime beneficiaries. (Tooze, p. 65)

In Germany, the weakness of political institutions and democracy in general, was unable to prevent Hitler and the National Socialists from using the politics of relief to consolidate power, unlike the United States, where the centralization of revenue collection was matched with a decentralization of relief administration and expenditures.

Histories of the New Deal that emphasize the centralizing nature of an expanding national government, usually fail to recognize the important constraints placed on national authority by vesting administrative controls at the state or local level. Calomiris's (2010) discussion of New Deal banking policy revolves around the contradiction between the New Dealer's understanding that the fragile nature of the unit banking system in the United States had been an important element in the collapse of the banks between 1929 and 1933, and the New Deal policy reforms that strengthened unit banking, particularly deposit insurance. As Calomiris explains, unit banking, and even the fragmented nature of the Federal Reserve System, was a political outcome motivated by the desire to maintain local and state control over the banking system (even at substantial costs in the efficiency of the system). These forces

\footnotetext{
${ }^{15}$ For the last point see Wallis et al. (2006).

16 Tooze (2007, p. 37). This paragraph is based on Tooze (ch. 3, pp. 37-66).
} 
manifested themselves immediately in the administration of relief. And just as the relief system adopted a national framework within which independent state operations could be coordinated, so in banking policy the financial 'lockdown' of banks described by Grossman and Meissner (2010) provided a national solution to the fragility of the unit banking system, within which the state and local control of banks stressed by Calomiris was allowed to continue.

The extent to which New Deal relief and banking policy represented 'centralization' is thus a matter of interpretation, rather than an obvious conclusion. The national government came to play a relatively more important role, within a framework that enabled significant state independence. But by putting such a system in place for the first time in American history, the perception that the national government could not provide a wider range of public services in a legitimate way began to change.

\section{After 1939}

The New Deal did create a larger role for the national government in the provision of social welfare, but not just any social welfare programme could have succeeded. The system in place under FERA in 1933 and 1934 was unsustainable outside of emergency conditions, and so, probably, was the administration of the WPA. The impersonal guarantees embedded in the Social Security Act, both for individuals and states, were critical elements of the acceptance by Congress, the states, and the public. In exactly the same way, not just any call for American involvement in the growing global military conflict between 1939 and 1941 would have garnered public support. Were a similar set of institutions at work between 1939 and 1941 ?

Roosevelt and the Americans did not offer Churchill and the Allies a set of matching grant formulas in 1941. Bringing America into the war effort, however, did not involve convincing the British, or the Russians, French, or Chinese about the viability of new international institutional arrangements. It was Congress and the American public that needed to be convinced. Churchill and Stalin saw American participation in the war effort as a matter of national survival; ideology and promises for the long term were easily negotiable. For Roosevelt, American participation was not a matter of national survival because the American people did not feel that it was. ${ }^{17}$ How then could the American people trust any arrangements made by Roosevelt with Churchill, much less Stalin?

Two elements were central. In 1933, when state and local governments were in deep financial distress, the national government was, temporarily, in a position where it could set

\footnotetext{
${ }^{17}$ Hans Morgenthau makes the point about Roosevelt, Churchill, and Stalin this way: 'In other words, for Churchill and Stalin the Second World War was the instrument of a foreign policy whose objectives had existed before the outbreak of hostilities, and were bound to continue to exist when the war had come to an end. For Roosevelt, as has been pointed out in another context, the war was an end in itself, its purpose exhausted with total victory and unconditional surrender. Churchill and Stalin knew that they were fighting for the perennial interests of their respective countries, for which Pitt and Castlereagh, Peter the Great and Alexander I had fought. For Roosevelt, as for Wilson before him, the war was being fought for universal humanitarian ideals, this time formulated in the Four Freedoms and the Atlantic Charter, yet, as before, unrelated to the concrete distribution of power which the United States had a vital interest in creating after the end of hostilities' (Morgenthau, 1952, p. 97). You can see in the passage the personalization of Roosevelt's foreign policy, but the need for Roosevelt to package his war plans in a manner acceptable to the public motivated the call to universal ideals.
} 
the agenda. In 1940 and 1941, the United States was in the same position vis-à-vis Britain, Russia, and the other Allies. The Allies made such large demands on the material resource of the United States that Roosevelt could reasonably ask for concessions in ordering the postwar world. The first formal statement of their plans came as a joint communication issued by Roosevelt and Churchill after their meeting in August 1941. The 'Atlantic Charter' was in form a 'New Deal for the world'. ${ }^{18}$ The Charter read like a New Deal document:

Fifth, they [the UK and US] desire to bring about the fullest collaboration between all nations in the economic field with the object of securing, for all, improved labour standards, economic advancement and social security; and Sixth . . . they hope to see established a peace which will afford to all nations the means of dwelling in safety within their own boundaries, and which will afford assurance that all the men in all the lands may live out their lives in freedom from fear and want.

Although Churchill's role in drafting the Charter and setting policy was just as important as Roosevelt's, the Americans' position of material strength enabled them to demand concessions in the form of post-war planning from 1940 on.

During the New Deal, language and planning such as this had produced real, concrete, national government institutions that, for the first time in American history, tried to guarantee freedom from fear and want. Conditions like those in 1941 would not persist forever. Americans could not believe that their Allies would always hold firm to their promises, but could they believe that their own national government could honour these promises? Could Americans believe that their government would use its position in international affairs to push for the formation of concrete institutions that would create the possibility for coordination of international behaviour with respect to economic, political, social, and humanrights problems?

The American experience under the New Deal, therefore, was the second important element in 1941. Americans probably would have entered the war at the end of 1941 after Pearl Harbor and Hitler's declaration of war, whether or not the New Deal had happened. The question is whether Americans would have believed that their government would conduct war and post-war policy in a way that created institutions that enabled a greater degree of credible coordination in the post-war world, had it not been for the New Deal. Were Americans willing to follow up those commitments with real institutions and rules, even at substantial costs to themselves?

Roosevelt articulated the four freedoms in the state of the union address in January 1941; the Atlantic Charter was issued in August 1941 - all before Pearl Harbor forced the US into the active war. In January of 1942, the Allies issued the 'Declaration of United Nations Proclamation', signed by Russia and China as well as the US and UK, that committed the allies to 'a common program of purposes and principles embodied in the Joint Declaration [the Atlantic Charter]'. As war preparations and execution moved forward, so did planning for a set of international institutions, culminating in the Bretton Woods conference in July 1944 that led to the creation of the IMF and IBRD (World Bank), and the Dumbarton Oaks conference in August to October 1944, that led to the creation of the United Nations. There was nothing inevitable about any of these developments; similar efforts at establishing multilat-

\footnotetext{
18 The argument that the New Deal served as a template for the shape of the international institutions developed in the war and post-war period is developed fully in the work of Elizabeth Borgwardt (2005).
} 
eral institutions after the First World War were mortally weakened by the unwillingness of the United States to participate.

The New Deal changed that willingness. Not only was the United States, reluctantly, participating in international coordination, the United States had a plan and a vision for how the coordination should be structured:

the domestic origins of the specific contours of the postwar international order lie in the historical experience of one liberal state: the United States during the New Deal. By 1941, having finally accepted that the United States could not effectively isolate itself from the world, US policymakers determined instead to remake the world in the American image. (Burley, 1993, p. 129) ${ }^{19}$

The image the US sought to impose on the world after 1941 was the American world that emerged after 1933. The New Deal was more than the image for the new world, it was the rationale for the new world.

How committed were Americans to these arrangements? Table 1 provides some important and interesting evidence on the share of GDP devoted to military and to social welfare programmes by year. By fiscal year 1948, the size of the national government expenditures had fallen back to the level of the late New Deal, 11 per cent of GDP, 3 per cent on military, and 4 per cent on social welfare. But then the commitments came home to roost. Military expenditures (including Marshall Plan funds) increased from 3 to 5 per cent, and then jumped to 7 and 13 per cent in 1951 and 1952, with the Korean war, and did not fall much below 10 per cent until the 1970s. Social welfare expenditures (including veterans' benefits) fluctuated between 3 and 4 per cent of GDP until the late 1950s, when they began to rise as the commitments made in 1935 to provide old-age and disability insurance came on line and began to expand. In the 1960s military expenditures would remain high, and social welfare expenditures would continue to grow (Figure 1). America's New Deal commitments were honoured, and the world changed.

\section{Lessons}

Social coordination, both within and across nations, is predicated on the credible belief that individuals or nations who act in a coordinated way will not be taken advantage of. This requires the existence of demonstrably effective institutions capable of coordinating political actions and policies that are, to a large extent, impersonal. The economic and political history of the world from 1914 to 1941 is filled with incidents in which failures to coordinate led to war and economic crises, and continued to make crises both deeper and longer lasting. The evocative phrase 'beggar thy neighbour' captures the individual and national rationality that led to decisions that produced collectively disastrous outcomes. We can, with Feinstein et al. (1997) agree that 'The lesson of Versailles had been absorbed: a sufficient degree of

19 'In a unique moment of history after World War II, the United States found itself with an unprecedented power to create rules and organizations - international regimes - that laid down a global framework for international relations while protecting American economic and security interests. Largely because of US enthusiasm, such international regimes as the United Nations, the International Monetary Fund (IMF), the World Bank, and the General Agreement on Tariffs and Trade (GATT) were born. Amid this burst of institutional creativity, publicists spoke of entering 'the American Century.' Keohane and Nye (1985, p. 148) 
international coordination and cooperation had to be established if stability and prosperity were to be achieved', but that leaves us short of an explanation of how the lesson was implemented. How were arrangements devised within and between countries to alter the incentives of individuals and nations to coordinate in a crisis?

American political history is dominated by the ingrained fear that the democratic process does not automatically produce cooperative behaviour that is reciprocated. This is not just true in international affairs, but within the boundaries of the United States and, even, within the boundaries of individual states, counties, and cities. What is often unappreciated is that this is not simply a fear about the size of government, about big government, or about the national government, but these are really fears about the coordination process. As Guy Callender explained over a century ago (1902), when Americans believe that the coordination problems have been solved, they are more than willing to use their governments (although he uses a different vocabulary to state the proposition). In the simplest terms, if those who benefit pay, and those who lose are compensated, Americans are willing to use their governments to tackle problems. FDR famously captured the essence of the phenomenon when he was asked about the economics of Social Security payroll taxes in 1941:

In the course of this discussion I raised the question of the ultimate abandonment of the pay roll taxes in connection with old age security and unemployment relief in the event of another period of depression. I suggested that it had been a mistake to levy these taxes in the 1930s when the social security program was originally adopted. FDR said, 'I guess you're right on the economics. They are politics all the way through. We put those pay roll contributions there so as to give the contributors a legal, moral, and political right to collect their pensions and their unemployment benefits. With those taxes in there, no damn politician can ever scrap my social security program. Those taxes aren't a matter of economics, they're straight politics. ${ }^{20}$

When Roosevelt and the Democrats came to power in March 1933 and decided to experiment with the provision of social welfare services on a wide scale, there was no experience in American history that would suggest that they would do so fairly and impartially. In fact, the first 2 years of relief under FERA and Hopkins were plagued by the politics of relief, although perhaps not the way modern scholars see politics in the allocation of grants between the states. ${ }^{21}$ Since the national government had discretionary control over the allocation of grants to states, the relief administrator possessed the ability to coerce states to cooperate. These problems were solved by an institutional design that worked through allocating discretion and rules in a way that created a more integrated government structure. The Social Security Act institutions were ones in which the centre coordinated the state through positive incentives rather than fiscal coercion, and the states had credible guarantees of independence because they controlled the purse strings.

The United States found, for the first time in its history, a confidence that the national government could undertake large projects and produce a set of roughly impersonal outcomes. This seems hard to believe in 2010, when the American national government is

\footnotetext{
${ }^{20}$ The quotation is attributed to Luther Gullick, who was working on a study of federal, state, and local fiscal relationships when he talked to FDR in 1941. See DeWitt (2005).

21 The evidence seems to be fairly clear that relief spending was the least politicized of all the New Deal grant programmes, and adhered most closely to the goal of relieving the unemployed (Wallis et al., 2006).
} 
the largest and most powerful government in the world. But the numbers do not lie. It was not until 1933 that the American public and their elected representatives in Congress and the Presidency were willing to let the non-military part of the national government spend anything approaching 1 per cent of GDP. ${ }^{22}$ This was a political economy accomplishment of considerable magnitude.

What, then, were the concrete lessons of the New Deal, remembered or forgotten?

One of the forgotten lessons is the importance of policies that ameliorate the adverse personal and social costs of a serious economic downturn, both for politics and economics. So much of the economics and economic history research into the 1930s has focused on the narrow question of whether the New Deal promoted or impeded economic recovery, that we have forgotten that the New Deal goals included 'relief, recovery, and reform' and that relief came first. In the simplest political terms, providing relief to ameliorate economic suffering can buy a precious breathing space for political leaders and more room to operate on the economic side. Leaders in both Germany and the United States saw the logic of the simple argument in 1933 and 1934. The fiscal crisis in Greece in the winter of 2009-10, the result of long-term structural flaws exacerbated by the economic recession, highlights how difficult it is to pursue policies in the midst of an economic crisis that will make many citizens worse off. The current debate in the United States over the size of the budget deficit threatens to produce a reduction in government assistance to individuals and, critically, to states. The political costs of a policy that puts economic recovery ahead of taking care of people can be extremely high, as Herbert Hoover learned in the election of 1932.

Simply pursuing ameliorating policies by passing out money is, however, unlikely to be sustainable. The importance of coordination as a means of addressing pressing social problems is the second lesson. New Deal policy-makers certainly learned that cooperation and coordination across states and economic groups was a necessary part of making changes in the welfare system permanent. This was a lesson learned domestically in the 1930s that was applied internationally in the 1940s. Contemporaries and historians alike understood that the lack in international coordination played a central role in both the economic situation in the 1920 s and the 1930s, and the return to conditions of world war after 1939. Political leaders around the world appear to have remembered this lesson in the autumn of 2008 and onwards, when they collectively acted to address the economic crisis. Whether it will continue to be applied as the Great Recession lingers is less clear. Many Americans, for example, remain outraged or concerned that the immediate beneficiaries of the government's attempt to stem the crisis were the very actors who caused the crisis, the banks and financial institutions. The difficulty of constructing a new set of institutional arrangements that credibly ensure that taxpayers will not suffer for the benefit of financial institutions in the future emphasizes the magnitude of the New Deal accomplishment. Even if we agree with Calomiris (2010) and Grossman and Meissner (2010) that New Deal financial regulations came with some cost in efficiency, we should not ignore that those regulations were part of the pattern of social coordination and compromise that formed the social infrastructure for the following 75 years of impressive economic growth.

The last lesson to learn from the New Deal and the Second World War is that coordination failures can have enormous social costs. The gains from avoiding coordination failures are so large, that whether the institutions that enable coordination are first, second, or third best

22 See Wallis and Weingast (2005) for a detailed discussion of why the national government was unable, despite constant attempts, to invest in transportation before the Civil War. 
may be a matter of little moment. While we have not forgotten this lesson, we are often in danger of forgetting how coordination problems are solved. The tendency of economists to evaluate the New Deal policies only from the standpoint of their effects on the economic recovery or the efficiency of the economy, under the assumption that the coordination problems have already been solved, is problematic. The relief programmes' primary purpose was to ameliorate the adverse economic effects of the depression. Almost certainly the relief programmes had negative effects on the economy along some margins, as did some policies in banking and finance, agricultural price supports, and industrial codes. Does that mean that the New Deal was a net loss to the American economy, the larger American society, or global society? I, personally, do not think so, even though I have not and cannot provide solid quantitative evidence (neither can those who argue that the New Deal was a net loss). These questions are complicated, but that does not mean that economists should not consider the benefits of social coordination as a primary lesson of the 1930 s.

\section{References}

Alston, L., and Ferrie, J. (1999), Southern Paternalism and the American Welfare State: Economics, Politics, and Institutions in the South, 1865-1965, New York, Cambridge University Press.

Anderson, G. M., and Tollison, R. D. (1991), 'Congressional Influence and Patterns of New Deal Spending, 1933-1939', Journal of Law and Economics, 34, 161-75.

Arrington, L. (1969), 'The New Deal in the West: A Preliminary Statistical Inquiry', Pacific Historical Review, 38, 311-16.

- (1970), 'Western Agriculture and the New Deal', Agricultural History, 49, 337-51.

— (1983), 'The Sagebrush Resurrection: New Deal Expenditures in the Western States, 1933-1939', Pacific Historical Review, 52(1), 1-16.

Bateman, F., and Taylor, J. E. (2003), 'The New Deal at War: Alphabet Agencies' go to War Expenditure Patterns, 1940-1945', Explorations in Economic History, 40, 251-77.

_ — (2007), 'Does the Distribution of New Deal Spending Reflect and Optimal Provision of Public Goods?', Economics Bulletin, 8, 1-10.

Bernstein, B. J. (1968), 'The New Deal: The Conservative Achievements of Liberal Reform', in B. J. Bernstein (ed.), Towards a New Past: Dissenting Essays in American History, New York, Pantheon Books, 263-88.

Borgwardt, E. (2005), A New Deal for the World: America's Vision for Human Rights, Cambridge, MA, Belknap Harvard University Press.

Brown, M. K. (1999), Race, Money and the American Welfare State, Ithaca, NY, Cornell University Press.

Burley, A. M. (1993), 'Regulating the World: Multilaterlism, International Law, and the Projection of the New Deal', in J. G. Ruggie (ed.), Multilateralism Matters: The Theory and Praxis of an Institutional Form, New York, Columbia University Press.

Callender, G. S. (1902), 'The Early Transportation and Banking Enterprises of the States', Quarterly Journal of Economics, 17(1), 111-62.

Calomiris, C. W. (2010), 'The Political Lessons of Depression-Era Banking Reform', Oxford Review of Economic Policy, 26(3), 540-60.

Couch, J. F., and Shugart, W. F. (1998), The Political Economy of the New Deal, Cheltenham, Edward Elgar.

— - (2000), 'New Deal Spending and the States: The Politics of Public Works', in J. Heckelman, J. Moorehouse, and R. Whaples (eds), Public Choice Interpretations of American Economic History, Boston, MA, Kluwer, 105-22.

DeWitt, L. (2005), 'Research Note \#23, Luther Gulick Memorandum re: Famous FDR Quote', Reports \& Studies Research Notes \& Special Studies by the Historian's Office, Social Security Administration, http://www.ssa.gov/history/Gulick.html 
Eichengreen, B. (1990), Elusive Stability: Essays in the History of International Finance, 1919-1939, New York, Cambridge University Press.

- (1992), Golden Fetters, The Gold Standard and the Great Depression, 1919-1939, New York, Oxford University Press.

— (2007), The European Economy since 1945: Coordinated Capitalism and Beyond, Princeton, NJ, Princeton University Press.

Feinstein, C. H., Temin, P., and Toniolo, G. (1997), The World Economy between the World Wars, New York, Oxford University Press.

Fishback, P. V. (2010), 'US Monetary and Fiscal Policy in the 1930s', Oxford Review of Economic Policy, 26(3), 385-413.

- Haines, M., and Kantor, S. (2001), 'The Impact of the New Deal on Black and White Infant Mortality in the South', Explorations in Economic History, 38, 93-122.

_ _ _ (2007), 'Births, Deaths, and New Deal Relief During the Great Depression', Review of Economics and Statistics, 89, 1-14.

— Horrace, W. C., and Kantor, S. (2005), 'Did the New Deal Programs Stimulate Local Economies? A Study of Federal Grants and Retail Sales during the Great Depression', Journal of Economic History, 65(1), 36-71.

- - - (2006), 'The Impact of New Deal Expenditures on Mobility During the Great Depression', Explorations in Economic History, 43, 179-222.

- Kantor, S., and Wallis, J. J. (2003), 'Can the New Deal's Three R's Be Rehabilitated? A Programby-Program, County-by-County Analysis', Explorations in Economic History, 278-307.

- Neumann, T., and Kantor S. (2010), 'The Dynamics of Relief Spending and the Private Urban Labor Market During the New Deal', Journal of Economic History.

Fleck, R. K. (1999a), 'The Marginal Effect of New Deal Relief Work on County-level Unemployment Statistics', Journal of Economic History, 59(3), 659-87.

- (1999b), 'Electoral Incentives, Public Policy, and the New Deal Realignment', Southern Economic Journal, 65(3), 377-404.

- (2001a), 'Inter-party Competition, Intra-party Competition, and Distributive Policy: A Model and Test Using New Deal Data', Public Choice, 108(1), 77-100.

- $(2001 b)$, 'Political Economy of New Deal Spending(??)', Explorations in Economic History.

- (2008), 'Voter Influence and Big Policy Change: The Positive Political Economy of the New Deal', Journal of Political Economy, 116(1), 1-37.

Grant, N. (1990), TVA and Black Americans: Planning for the Status Quo, Philadephia, PA, Temple University Press.

Grossman, R. S., and Meissner, C. M. (2010), 'International Aspects of the Great Depression', Oxford Review of Economic Policy, 26(3), 318-38.

Johnston, L. D., and Williamson, S. H. (2008), 'What Was the US GDP Then?', Measuring Worth, available at http://www.measuringworth.org/usgdp/

Katz, M. B. (1986), In the Shadow of the Poor House: A Social History of Welfare in America, New York, Basic Books.

Katznelson, I. (2005), When Affirmative Action was White: An Untold Story of Racial Inequality in the Twentieth Century, New York, Norton.

Kennedy, D. M. (1999), Freedom from Fear: The American People in Depression and War, 1929-1945, New York, Oxford University Press.

Keohane, R. O., and Nye, J. S., Jr (1985), 'Two Cheers for Multilateralism', Foreign Policy, 60, $148-67$.

Lieberman, R. C. (1998), Shifting the Color Line: Race and the American Welfare State, Cambridge, Harvard University Press.

Morgenthau, H. J. (1952), American Foreign Policy: A Critical Examination, London, Methuen \& Co. (This is a British edition of In Defense of the National Interest: A Critical Examination of American Foreign Policy, published in the United States in 1951.)

National Resources Planning Board (1942), Security, Work, and Relief Policies, 1942, Washington, United States Government Printing Office.

Patterson, J. T. (1986), America's Struggle Against Poverty, 1900-1985, Cambridge, MA, Harvard University Press. 
Reading, D. C. (1973), 'New Deal Activity and the States', Journal of Economic History, 36, 792-810.

Temin, P. (1989), Lessons from the Great Depression, Cambridge, MA, MIT Press.

Tooze, A. (2007), The Wages of Destruction, New York, Viking.

Wallis, J. J. (1981), 'Work Relief and Unemployment in the 1930s', unpublished PhD Dissertation, University of Washington.

- (1984), 'The Birth of the Old Federalism: Financing the New Deal', Journal of Economic History, 44 139-59.

- (1987), 'Employment, Politics, and Economic Recovery in the Great Depression', Review of Economics and Statistics, 59, 516-20.

— (1991), 'The Political Economy of New Deal Fiscal Federalism', Economic Inquiry, 29, 510-24.

- (1998), 'The Political Economy of New Deal Spending, Revisited, With and Without Nevada' Explorations in Economic History, 35, 140-70.

- (2001), 'The Political Economy of New Deal Spending, Yet Again: A Reply to Fleck', Explorations in Economic History, 38, 305-14.

- Oates, W. (1998), 'The Impact of the New Deal on American Federalism' in M. Bordo, C. Goldin and E. N. White (eds). The Defining Moment: The Great Depression and the American Economy in the Twentieth Century, NBER, University of Chicago Press.

- Weingast, B. R. (2005), 'Equilibrium Impotence: Why the States and not the American National Government Financed Economic Development in the Ante-Bellum Era', NBER Working Paper W11397.

- Fishback, P. V., and Kantor, S. (2006), 'Politics, Relief, and Reform: The Transformation of America's Social Welfare System during the New Deal', in Goldin and Glaeser (eds). Corruption and Reform, Chicago, IL, University of Chicago Press.

Whatley, W. (1983), 'Labor for the Picking: The New Deal in the South', Journal of Economic History, 43 905-25.

Williams, E. A. (1939), Federal Aid for Relief, New York, Columbia University Press.

Wright, G. (1974), 'The Political Economy of New Deal Spending', Review of Economics and Statistics, 59 $30-8$. 